\title{
Two new species of oppioid mites from Turkey (Acari: Oribatida)
}

\author{
AYŞE TOLUK ${ }^{1}$, NUSRET AYYILDIZ ${ }^{1} \&$ LUIS S. SUBÍAS ${ }^{2}$ \\ 1. Erciyes University, Faculty of Arts and Sciences, Department of Biology, 38039 Kayseri, Turkey. \\ atoluk@erciyes.edu.tr; nayildiz@erciyes.edu.tr \\ 2. Departamento de Zoologia, Facultad de Biologia-UCM, 28040 Madrid, Spain, subias@bio.ucm.es
}

\begin{abstract}
Two new oppioid oribatid mites, Moritzoppia unicarinata yozgatensis ssp. nov. of the family Oppiidae and Cosmogneta ozkani sp. nov. of the family Autognetidae are described from Turkey, using specimens collected in Yozgat Pine Grove National Park.
\end{abstract}

Key words: Oppioidea, Oppiidae, Autognetidae, Yozgat Pine Grove National Park, Turkey

\section{Introduction}

Yozgat Pine Grove National Park in Turkey was established in 1958 and is located within the borders of the Municipality of Yozgat. The black pine tree (Pinus nigra) grove of $265 h a$ is the nucleus of this area; the empty lands surrounding this area have also been added to the National Park by afforesting during the years of 1984-1986. Today, $800 \mathrm{ha}$ of lands have been taken under protection and mostly consist of black pine trees and oaks (Anonymous, 1988).

Works on oribatid mites of Turkey do not mention any data on Yozgat Pine Grove National Park (Özkan et al. 1988, 1994). To date, there has been no report on the oppioid subgenus Moritzoppia (Moritzoppia) Subias \& Rodriguez, 1988 and the genus Cosmogneta Grandjean, 1960 from Turkey (Özkan et al. 1988, 1994; Ayyıldız 1989; Baran \& Ayyıldız 2004a, b).

The genus Moritziella was described by Balogh (1983), with the type species, Oppia keilbachi Moritz, 1969, but it was an invalid name and was renamed by Subias and Rodriguez (1988) as Moritzoppia. So far, 15 species and 7 subspecies of the subgenus Moritzoppia (Moritzoppia) are known (Subias 2004).

The genus Cosmogneta was described by Grandjean (1960) with the type species Cosmogneta impedita Grandjean, 1960. The genus Cosmogneta is represented by only three species (Subias 2004).

This work describes a new subspecies of Moritzoppia unicarinata and a new species of Cosmogneta, on the basis of the materials collected from Yozgat Pine Grove National Park in Turkey.

Measurements are given in micrometers. The type materials are deposited in the Acarological Collection of the Zoological Museum, Erciyes University, Kayseri, Turkey. 


\section{Descriptions of new taxa}

Moritzoppia unicarinata yozgatensis ssp. nov.

Figs. 1-6

Measurements. Body length: 296-320 (holotype: 300), body width: 124-140 (holotype: 134). Six specimens were measured.

Prodorsum (Fig. 1). Rostrum rounded. Rostral setae 22 in length, arising on the dorsal surface of rostrum, curved inwards, with one cilia. There is a protuberance between the rostral setae. Lamellar setae 6 in length, arising near the costulae. Interlamellar setae 10 in length, on a pair of cristae in the interbothridial region. Distance between lamellar and interlamellar setae shorter than that between rostral and lamellar setae. Costulae in the shape of two inverted ' $\mathrm{V}$ ', transcostula well developed. One pair of tubercles outside of the costulae. Sensilla fusiform, with several distinct barbs.

Notogaster (Fig. 1). Elongate oval, 234 in length, its anterior and posterior margins conspicuously narrowed; anterior margin reaching to the level of anterior edge of bothridia. Crista absent. Ten pairs of notogastral setae; seta $c_{2} 20$ in length and smooth.

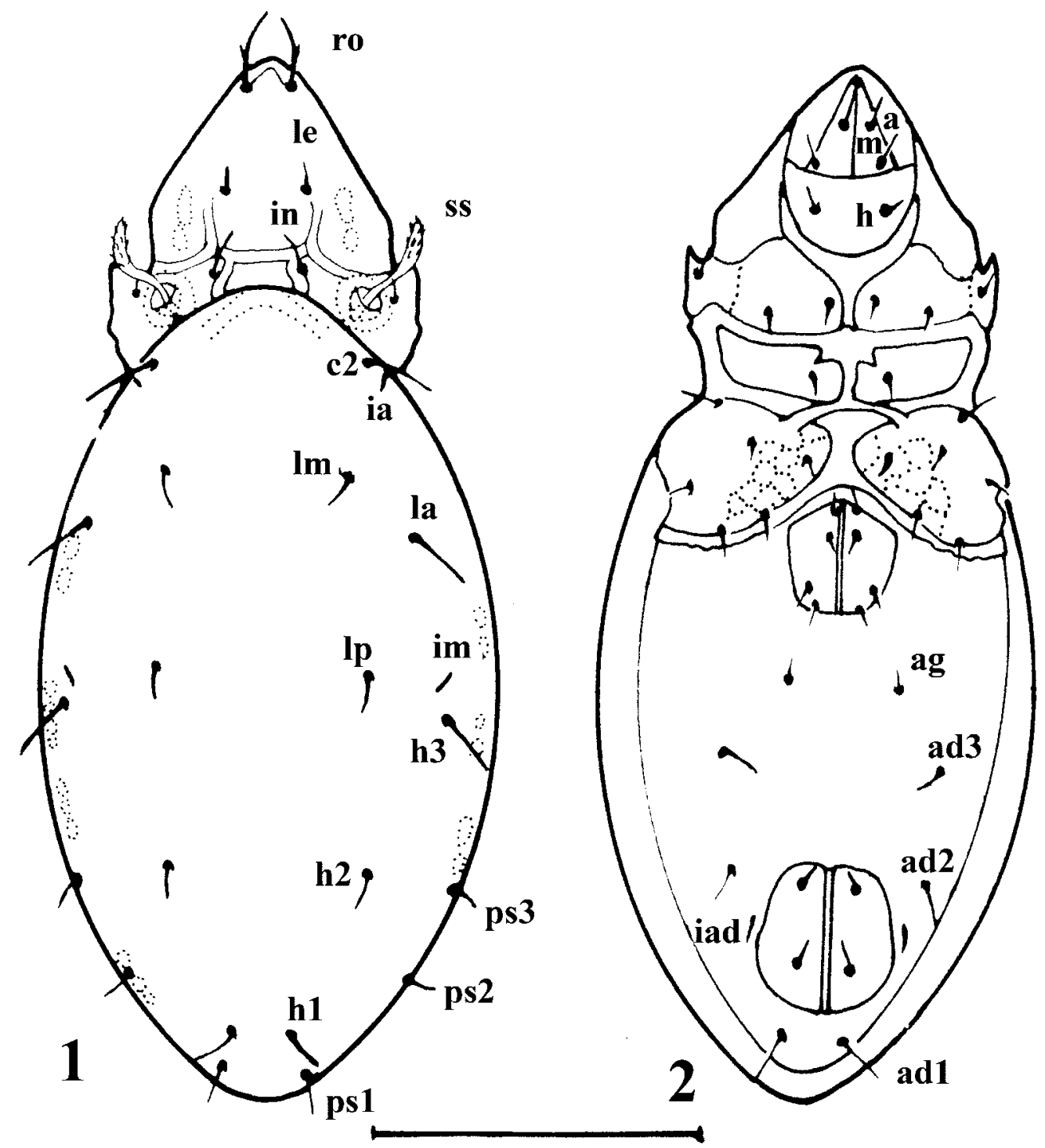

FIGURES 1-2. Moritzoppia unicarinata yozgatensis ssp. nov. - 1) Dorsal view, 2) Ventral view (scale bar for all figures $=100 \mu \mathrm{m}$ ). 
Ventral side (Fig. 2). Mentum 26 in length, 40 in width. Setae $m$ 10, setae $a 12$ in length. Epimeral setal formula 3-1-3-3. Epimeral regions 3 and 4 with polygonal network, but on epimere 2 polygonal network is visible only in median part. Genital plate 34 in length, 32 in width, with four pairs of setae. Anal plate 40 in length, 44 in width, with two pairs of setae. One pair of aggenital and three pairs of adanal setae. Distance between genital and anal plates 72. Lyrifissures $i a d$ situated in para-anal position. Adanal setae $a d_{1}$ in postanal, $a d_{2}$ in para-anal and $a d_{3}$ in preanal positions.

Legs (Figs. 3-6). All legs monodactylous, setation of leg segments is given in figures 3-6.
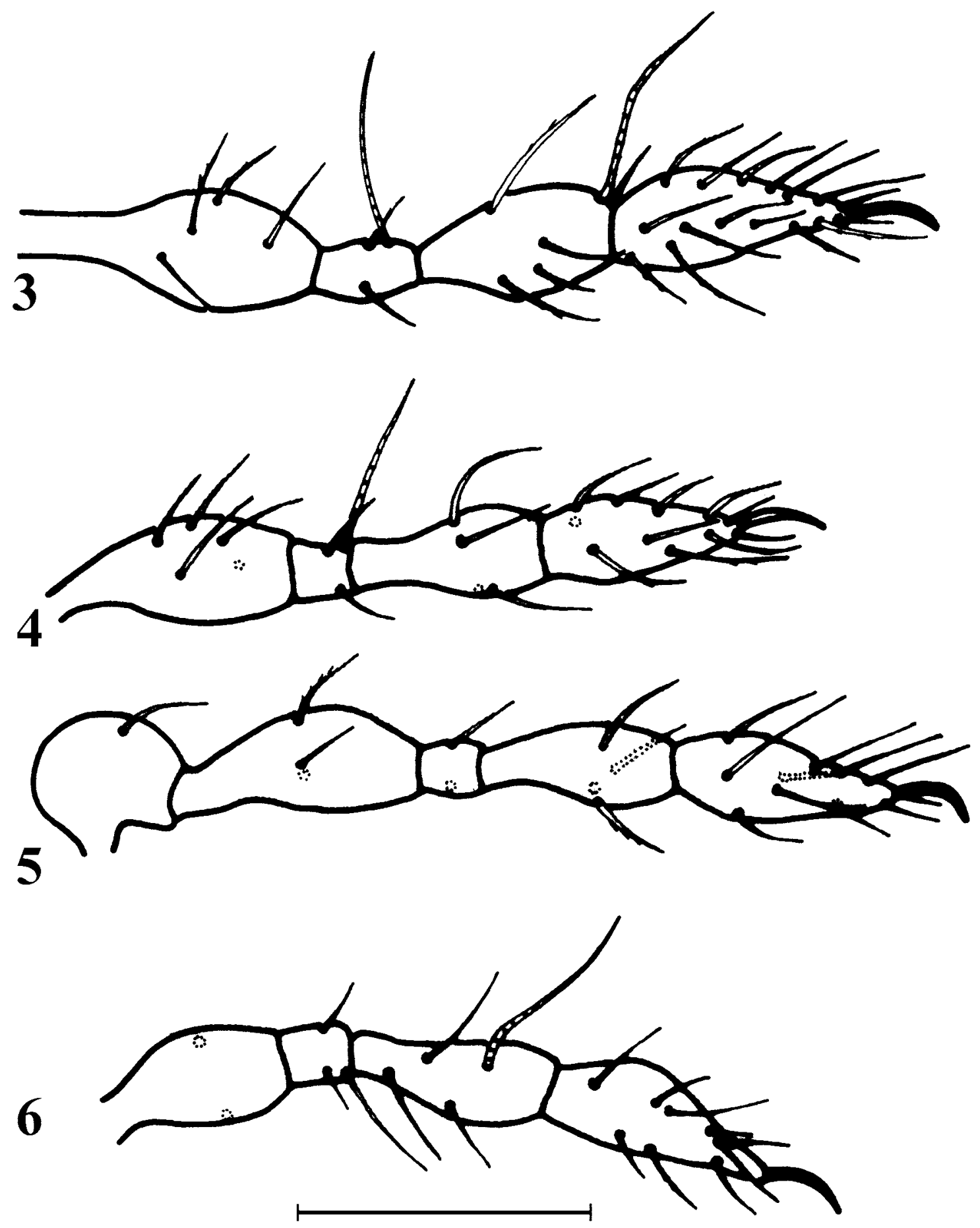

FIGURES 3-6. Moritzoppia unicarinata yozgatensis ssp. nov. -3) Leg I, 4) Leg II, 5) Leg III, 6) Leg IV (scale bar for all figures $=40 \mu \mathrm{m})$. 
Material examined. YÇMP-370, soil from Pinus nigra and Quercus spp. forest, N 3948.137', E 034'48.663', 1569 m, 18 Apr 2006, holotype and one paratype; YÇMP-363, as for the previous sample, $\mathrm{N}$ 39 48.140', E 034²48.666', 1563 m, 18 Apr 2006, one paratype YÇMP-379, as for the previous sample, $\mathrm{N}$ $39^{\circ} 48.122^{\prime}$, E $034^{\circ} 48.653^{\prime}, 1577$ m, 18 Apr 2006, three paratypes (one of them in the collection of L. S. Subias, Spain).

Etymology. Specific name yozgatensis is named after the locality, Yozgat, where the present new species was found.

Remarks. This new subspecies resembles Moritzoppia unicarinata clavigera described by Hammer (1952) from Northern Canada. However, it can be distinguished from the latter species by the following features: 1) there is a protuberance between the rostral setae in the new species (there is no protuberance between the rostral setae in M. unicarinata clavigera); 2) lamellar setae arising near the costulae in the new species (lamellar setae arising at the distal end of the costulae in M. unicarinata clavigera); 3 ) anterior margin of the notogaster reaches to the level of anterior margin of the bothridium in the new species (anterior margin of the notogaster reaches to the level of posterior margin of the bothridium in M. unicarinata clavigera).

Colloff \& Seyd (1991) redescribed M. clavigera by using syntypes. They stated that the translamella is absent the specimens they examined, although Hammer (1952) mentions that often the middle portion of the translamella is absent, or it is tripartite, and she shows it as complete in her figure. However, from the translamella point of view, our samples resemble the Hammer's figure (Hammer 1952). In the description, we used the transcostula instead of the translamella.

\section{Cosmogneta ozkani sp. nov.}

Figs. 7-17

Measurements. Body length 228-244 (holotype: 244), body width 104-116 (holotype: 114).
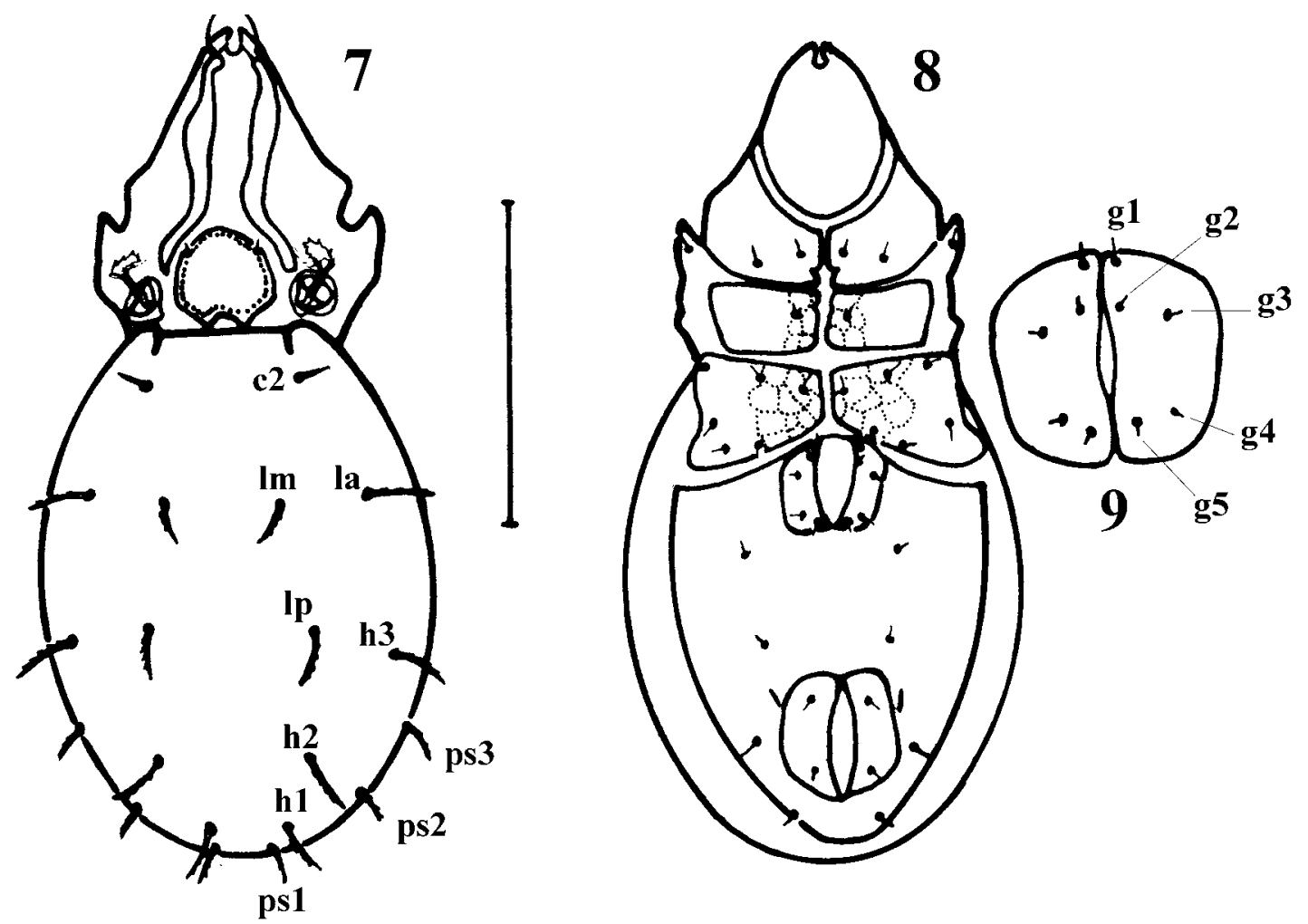

FIGURES 7-9. Cosmogneta ozkani sp. nov. -7) Dorsal view, 8) Ventral view, 9) Genital plates (scale bar for 7 and $8=$ $100 \mu \mathrm{m}, 9=40 \mu \mathrm{m})$. 
Prodorsum (Figs. 7, 10-13). Rostrum divided by deep median incision. Rostral setae smooth, 13 in length, arched inwards. The costulae long, parallel, widened at their median parts and reaching to the median incision of the rostrum. Lamellar setae 5 in length, arising at the distal end of the costulae, situated closer to rostral setae than to interlamellar setae. Interlamellar setae minute, 2 in length and arising in anterior one-third of the interbothridial protuberance. Lamellar and interlamellar setae smooth. Bothridia well developed. Sensilla with long stalk and little dilated, strongly barbed elliptical heads.

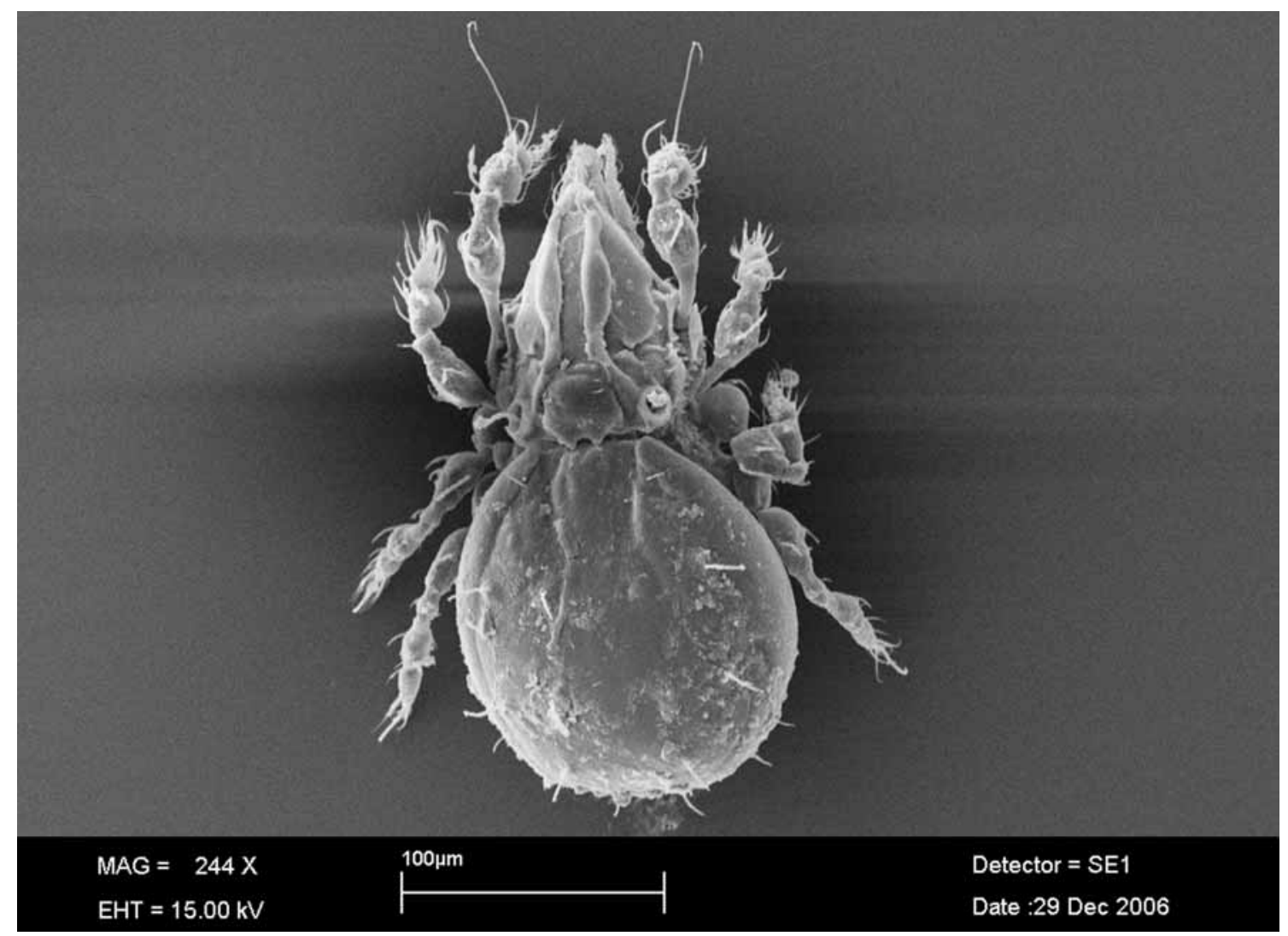

FIGURE 10. Cosmogneta ozkani sp. nov. —Dorsal view.

Notogaster (Figs. 7, 10). Oval, but straight anteriorly, with one pair of prominent humeral processes. Ten pairs of notogastral setae, thick and unilaterally barbed.

Ventral side (Figs. 8, 9). Epimeral regions 3 and 4 with polygonal network, but on epimere 2 polygonal network is visible only in median part. Epimeral setal formula 3-1-3-3. Genital plate 26 in length, 28 in width, with five pairs of setae. Form and position of genital setae as shown in Fig. 9. Anal plate 38 in length, 30 in width, with two pairs of setae. Aggenital setae and three pairs of adanal setae short and thin. Distance between genital and anal plates 38. Lyrifissure $i a d$ situated in para-anal position. Adanal setae $a d_{1}$ in postanal, $a d_{2}$ in para-anal and $a d_{3}$ in preanal position.

Legs (Figs. 14-17). All legs monodactylous. Setation of leg segments is given in figures 14-17.

Material examined. YÇMP-382, soil from Pinus nigra and Quercus spp. forest, N 3948.141', E 034'48.742', 1498 m, 12 May 2006, holotype, four paratypes; YÇMP-251, soil and litter from Pinus nigra and Quercus spp. forest, N $39^{\circ}$ 48.452', E 034 48.955', 1455 m, 01 Dec 2005, two paratypes; YÇMP-257, as for the previous sample, N 39 $48.460^{\prime}$, E $034^{\circ} 48.935^{\prime}, 1460 \mathrm{~m}, 01 \mathrm{Dec} 2005$, one paratype; YÇMP-258, as

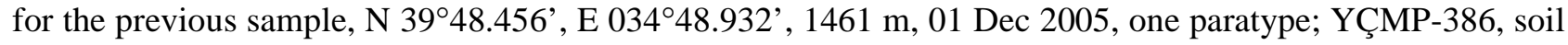
from Pinus nigra and Quercus spp. forest, N 3948.189', E 03448.713', 1505 m, 12 May 2006, one paratype; YÇMP-412, as for the previous sample, N 3948.138', E 03448.750', 1569 m, 12 May 2006, eleven paratypes (three of them in the collection of L. S. Subias, Spain); YÇMP-442, soil from uncovered area, N 39²48.022', E 34²4.557', 1548 m; 19 June 2006, seven paratypes. 


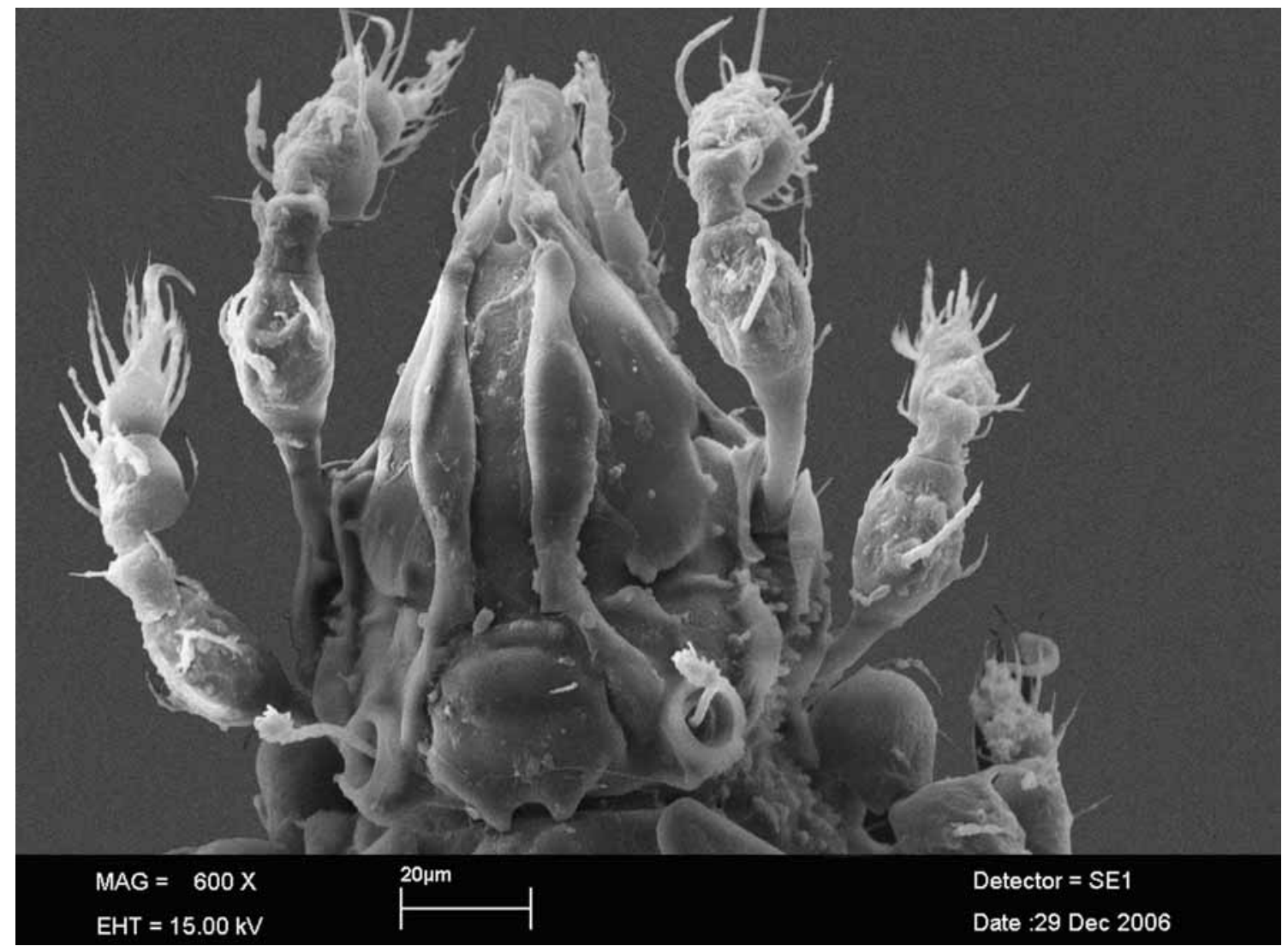

FIGURE 11. Cosmogneta ozkani sp. nov. —Prodorsum.

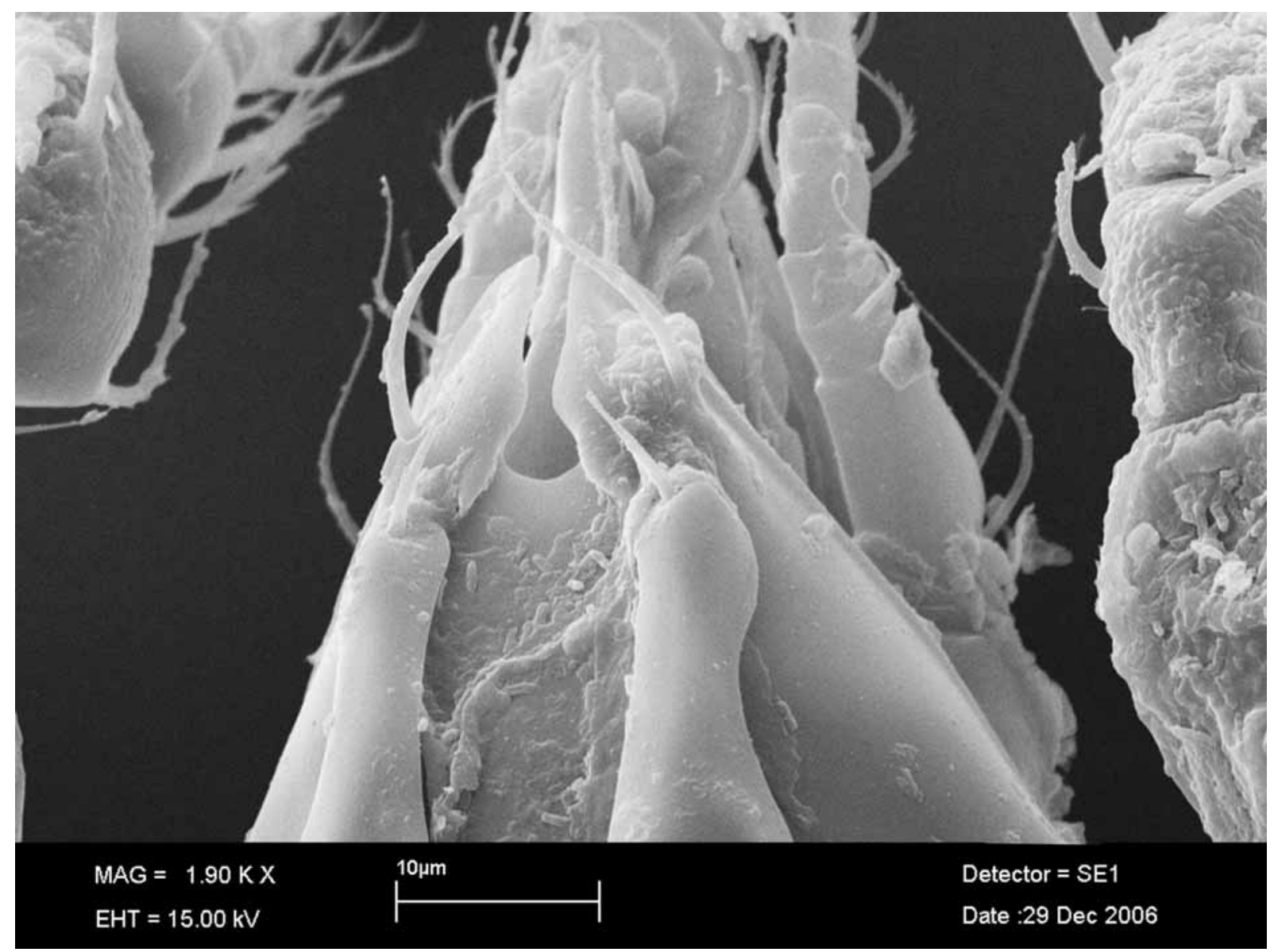

FIGURE 12. Cosmogneta ozkani sp. nov. — Rostrum and anterior part of lamella. 


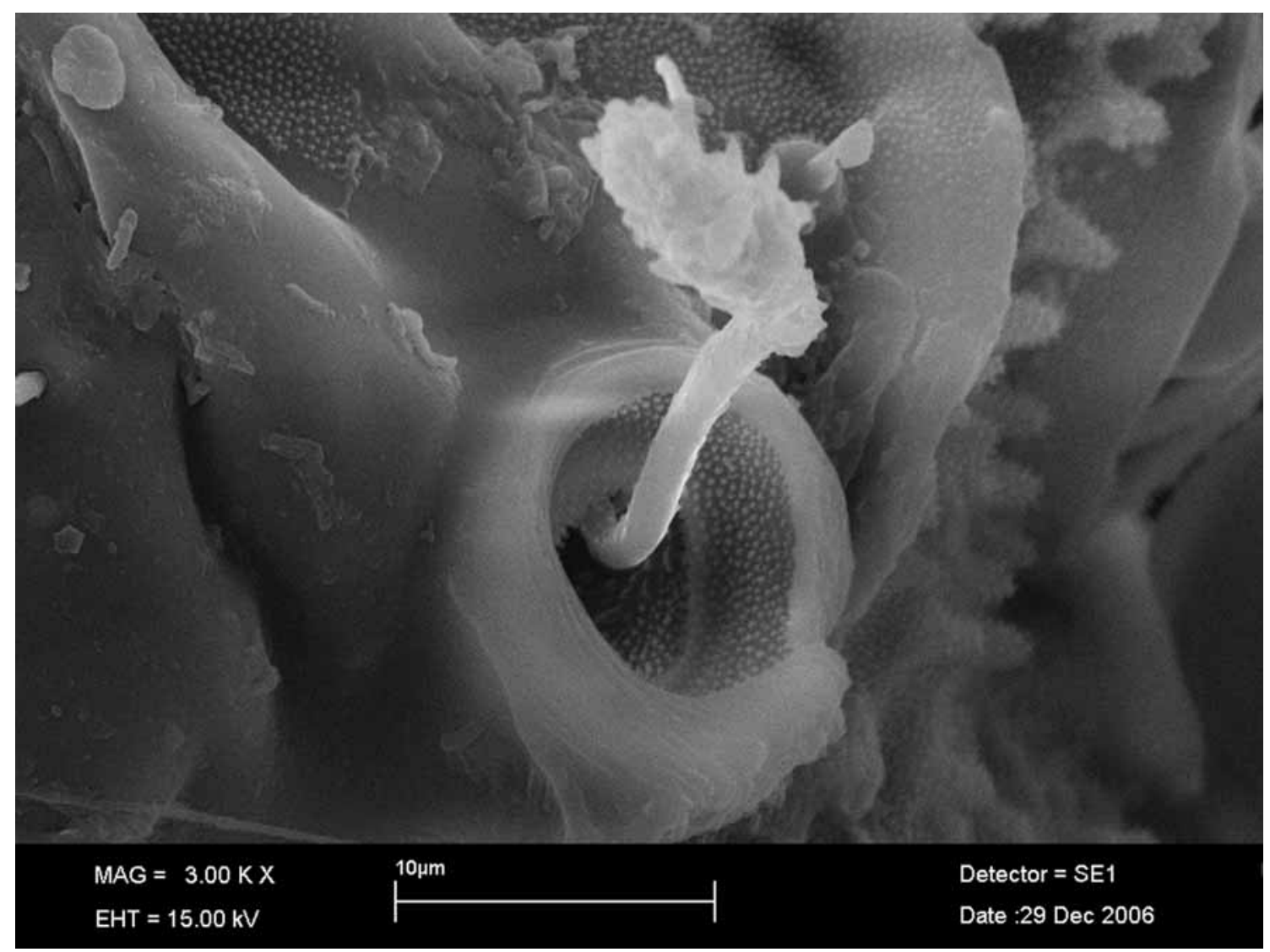

FIGURE 13. Cosmogneta ozkani sp. nov. — Bothridium and sensillus.

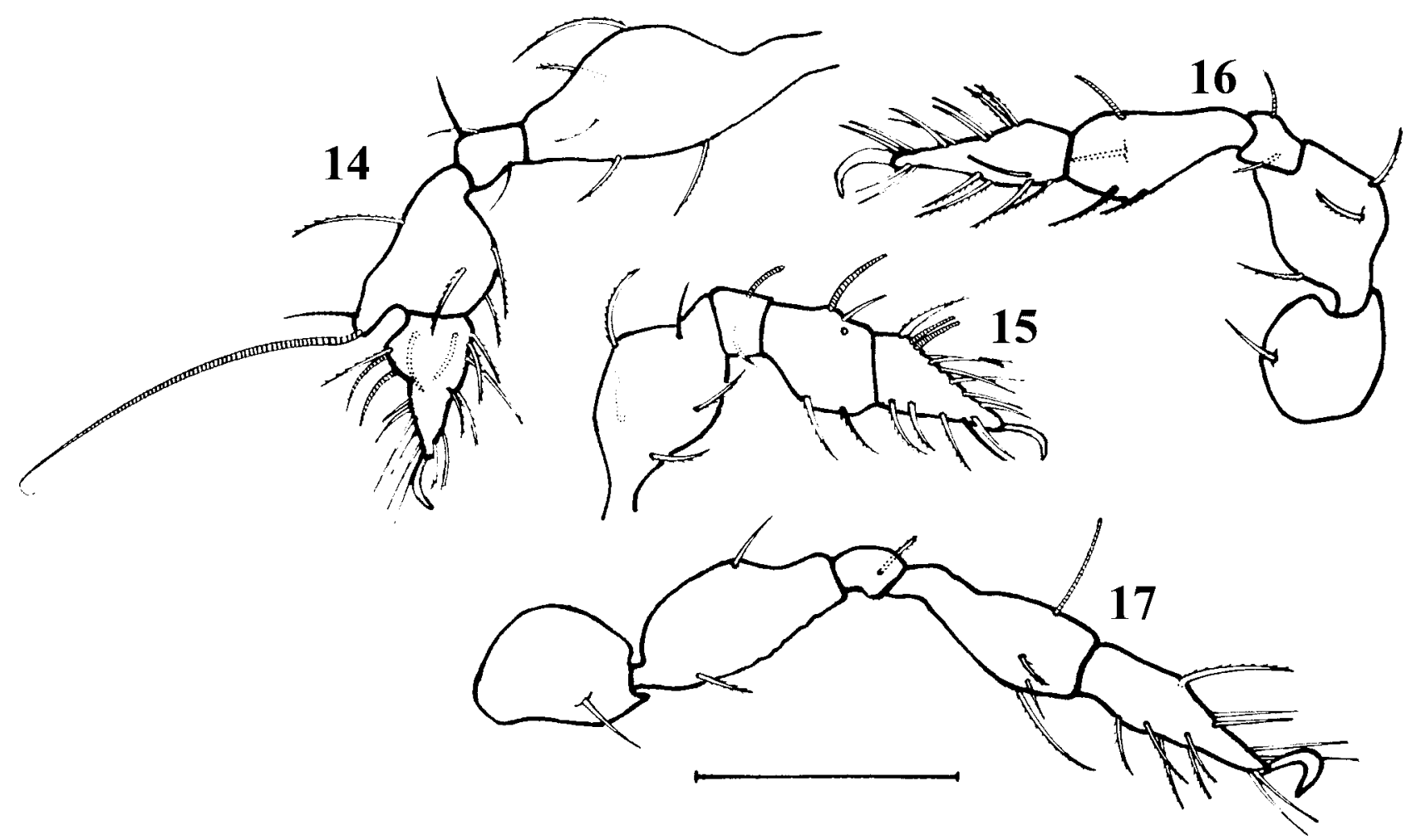

FIGURES 14-17. Cosmogneta ozkani sp. nov. - 14) Leg I, 15) Leg II, 16) Leg III, 17) Leg IV (scale bar for all figures $=40 \mu \mathrm{m})$. 
Etymology. This new species is named in honor of Prof. Dr. M. Özkan, Uludag University, Turkey, for his contribution to the knowledge of Turkish mite fauna.

Remarks. Until now, only three species of the genus Cosmogneta have been described, namely $C$. impedita Grandjean, 1960 from France, C. kargi Grandjean, 1963 from Germany and C. cassolai Bernini, Baratti and Avanzati, 1991 from Italy (Grandjean 1960, 1963; Bernini et al. 1991; Subias 2004).

These species, and C. ozkani, are all similar to each other but can be identified with the following key.

1. Lamellar setae present

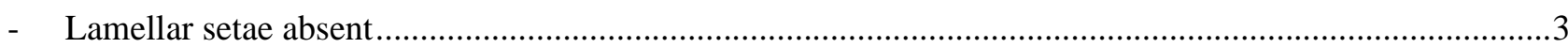

2. All notogastral setae thick and barbed; length $=228-244$........................................... C. ozkani sp.nov.

- The setae $c_{2}$ and $p s$ series short and thin, the remaining notogastral setae thick, apically enlarged and penicillate; length $=270$ and 271 C. cassolai Bernini, Baratti \& Avanzati, 1991

3. All notogastral setae thin and smooth; length $=300-320$ C. kargi Grandjean, 1963

- The setae $c_{2}$ and $p s$ series short and thin, the remaining notogastral setae thick, apically enlarged and curved spatula-like; length $=270-310$ C. impedita Grandjean, 1960

\section{Acknowledgements}

This study was supported by the Erciyes University Scientific Research Project Unit (Project No. FBA-0620). It is also part of the doctoral thesis of the first author. We thank Dr Owen Seeman for help in preparing the manuscript. We also thank anonymous reviewers for useful comments on the manuscript.

\section{References}

Anonymous, (1988) Yozgat Çamlığı Milli Parkı. T.C. Tarım Orman ve Köyişleri Bakanlığı Orman Genel Müdürlüğü Milli Parklar Dairesi Başkanlığı, Şafak Ofset ve Tipo Matbaacılık, Ankara.

Ayyıldız, N. (1989) Mites of the family Oppiidae (Acari, Oribatida) from Turkey. Journal of Natural History, 23, 13731379.

Balogh, J. (1983) A partial revision of the Oppiidae Grandejan, 1954 (Acari: Oribatei). Acta Zoologica Scientiarum Hungaricae, 29, 1-79.

Baran, Ş. \& Ayyıldız, N. (2004a) Oppia nitens C.L. Koch, 1836, a new species for the Turkish Fauna (Acari, Oribatida, Oppiidae). Turkish Journal of Zoology, 28, 111-113.

Baran, Ş. \& Ayyıldız, N. (2004b) Türkiye'de Ramusella Hammer, 1962 (Acari: Oribatida: Oppiidae) türleri için ilk kayitlar. Türkiye Entomoloji Dergisi, 28, 39-44.

Bernini, F., Baratti, M. \& Avanzati, A.M. (1991) Notulae Oribatologicae LIV. Cosmogneta cassolai (Acarida, Oribatida), a new species from Western Mediterranean Countries. Redia, 74, 467-479.

Colloff, M.J. \& Seyd, E.L. (1991) A new species of Moritzoppia from montane sites in the British Isles, with a redescription of M. clavigera (Hammer, 1952) (Acari: Oribatida: Oppiidae). Journal of Natural History, 25, 1067-1074.

Grandjean, F. (1960) Les Autognetidae n. fam. (Oribates). Acarologia, 2, 575-609.

Grandjean, F. (1963) Les Autognetidae (Oribates) Deuxieme partie. Acarologia, 5, 653-689.

Hammer, M. (1952) Investigations on the microfauna of Northern Canada, part I, Oribatidae. Acta Arctica, 4, 1-108.

Özkan, M., Ayyıldız, N. \& Soysal, Z. (1988) Türkiye akar faunası. Doğa Türk Zooloji Dergisi, 12, 75-85.

Özkan, M., Ayy1ldız, N. \& Erman, O. (1994) Check list of the Acari of Turkey. First Supplement. EURAAC News Letter, 7, 4-12.

Subias, L.S. (2004) Listado sistematico, sinonimico y biogeografico de los acaros oribatidos (Acariformes: Oribatida) del Mundo (Excepto fosiles). Graellsia, 60, 3-305.

Subias, L.S. \& Rodriguez, P. (1988) Los opidos (Acari, Oribatida) de los sabinares albares espanoles. VII. Generos Hypogeoppia, Oppiella y Lauroppia. Miscellania Zoologica, 11, 105-111. 